PRACE NAUKOWE UNIWERSYTETU EKONOMICZNEGO WE WROCLAWIU

Wyzwania dla spójności Europy -

gospodarka, zrównoważony rozwój, konkurencyjność

\title{
Barbara Wieliczko
}

Institute of Agricultural and Food Economics - National Research Institute

e-mail: Barbara.Wieliczko@ierigz.waw.pl

\section{COHESION POLICY OR COMMON AGRICULTURAL POLICY - WHICH OF THEM IS BETTER SUITED TO SUPPORT RURAL DEVELOPMENT IN POLAND?}

\section{POLITYKA SPÓJNOŚCI CZY WSPÓLNA POLITYKA \\ ROLNA - KTÓRA Z NICH JEST BARDZIEJ \\ DOPASOWANA DO WSPIERANIA ROZWOJU OBSZARÓW WIEJSKICH W POLSCE?}

DOI: $10.15611 /$ pn.2017.466.24

JEL Classification: R58, R11, O18

Summary: Rural areas in Poland are underdeveloped in comparison to urban areas and lag much behind their counterparts in the EU-15. Thus, there is still a need to support their development to accelerate their socio-economic convergence with better-off parts of the EU. Rural development is part of CAP objectives, but it is also supported from cohesion policy, especially as part of regional development. The analysis presented tries to assess which of these policies is better suited to support rural development in Poland. The research is based on document analysis and meta-evaluation of earlier studies. The results show that rural development measures within the CAP and instrument under cohesion policy are generally complementary to one another. However, there is much room for closer cooperation between the two policies to enlarge their positive impact on rural development. It seems that CAP can be regarded as better suited for rural development as it is directly devoted to rural areas. Yet, it is still too agriculture-orientated and thus it offers insufficient amount of resources and not enough instruments for other sectors of rural economy.

Keywords: cohesion policy, common agricultural policy, rural development.

Streszczenie: Obszary wiejskie w Polsce są słabiej rozwinięte w porównaniu z obszarami miejskimi oraz ze swoimi odpowiednikami w UE-15. W związku z tym nadal istnieje potrzeba wspierania rozwoju tych obszarów w celu przyspieszenia ich społeczno-ekonomicznej konwergencji z lepiej rozwiniętymi częściami UE. Rozwój obszarów wiejskich należy do priorytetów WPR, ale jest również wspierany ze środków polityki spójności, zwłaszcza w ramach rozwoju regionalnego. W przedstawionej analizie autor stara się ocenić, która $\mathrm{z}$ tych polityk jest lepiej dopasowana do wspierania rozwoju obszarów wiejskich w Polsce. Badanie opiera się na analizie dokumentów i metaewaluacji wcześniejszych badań. Wyniki pokazują, że działania wsparcia rozwoju obszarów wiejskich WPR i instrumenty polityki spójności są generalnie komplementarne wobec siebie. Pozostaje jednak wiele miejsca na ściślejszą 
współpracę między tymi politykami w celu zwiększenia ich pozytywnego wpływu na rozwój obszarów wiejskich. Wydaje się, że WPR może być uważana za lepiej dopasowaną do wspierania rozwoju obszarów wiejskich, gdyż bezpośrednio dotyczy tych obszarów. Jednak nadal WPR jest zbyt zorientowana na wspieranie rolnictwa, przez co niewystarczająca pula środków kierowana jest na inne niż rolnictwo sektory gospodarki wiejskiej.

Słowa kluczowe: polityka spójności, wspólna polityka rolna, rozwój obszarów wiejskich.

\section{Introduction}

Rural areas ${ }^{1}$ in Poland have received much financial support since the Polish EU accession. The funds stem from different structural funds and common agricultural policy (CAP). However, while the CAP funds are all earmarked for rural areas, the other funds generally do not have predefined level of funds to be used to support rural areas.

The question posed in the title is hard to answer within the limitation of this paper. However, it can be answered if we limit ourselves to the assessment of complexity of support and its adequacy to the developmental needs observed in the Polish rural areas. This approach should be seen as the first step to an in-depth analysis of the impact of the funds received from the CAP and cohesion policy on rural development in Poland. Yet, it is worth mentioning that the results of a study conducted by R. Crescenzi and M. Giua show that positive impact of cohesion policy is more visible in the regions with the most favourable socio-economic environment. At the same time the rural development measures under pillar 2 of the CAP generally also better serve the more developed regions. Yet, both pillars of the CAP are not "systematically linked with regional economic growth" [Crescenzi, Giua 2014].

The paper is based on the literature review. The analysis presented concerns the programming periods 2000-2006, 2007-2013 and 2014-2020.

The paper is divided into three key sections. The first of them focuses on the role of cohesion policy and CAP in rural development. The second one presents key facts concerning rural development in Poland after the Polish EU accession, while the third section presents the answer to the title question.

\section{Cohesion policy and CAP vs. rural development}

The EU cohesion policy is aimed at reducing the differences in socio-economic development [Dorożyński 2012]. It encompasses support for regions with different focus of the investment project it co-finances. In the current programming period

${ }^{1}$ Rural areas are defined in numerous ways in the literature. For the purpose of this paper we use the definition applied by the Polish Central Statistical Office (CSO), which is also used in all the Polish strategic documents and EU co-financed programmes. According to CSO rural areas are all these areas that are outside the administrative borders of urban areas and they cover $93.2 \%$ of the whole area of Poland. 
among key priorities are included, among others: research and innovation, resource efficiency; low-carbon economy, SMEs' competitiveness and social inclusion. This policy is financed through three funds: European Regional Development Fund (ERDF), European Social Fund (ESF) and Cohesion Fund. The amount of funds for rural areas is not predefined so in the case of most policy instruments both rural as well as urban beneficiaries can apply for support. This generally leads to a situation when the funds are received by the entities with higher capacity to successfully apply for them, which means the ones which are better-off. Thus, the probability for deadweight effect increases. However, in the programming period 2014-2020, based on the Polish partnership agreement, each regional programme has to indicate a share of funds to be devoted to rural areas amounting to app. 11\% [Zygadło 2014].

The EU CAP combines two pillars. Pillar 1 is focused on market related measures and direct payments, while pillar 2, also known as rural development policy, concentrates on structural measures ${ }^{2}$. As pillar 1 is sector-orientated it can directly only support rural development by leading to a development in agriculture. More flexible and diverse support can be obtained under pillar 2, although it is also skewed towards the agriculture.

The biggest advantage of the CAP support for rural development is the fact that the funds are almost exclusively eligible only to entities located in rural areas. Yet, most of the measures are limited to agriculture and thus concentrate on development of only one sector of rural economy.

Yet, there are also other measures targeted to both individuals and rural communities. Although the names of measures change from programming period to programming period, ${ }^{3}$ their key focus has remained the same since the Polish EU accession. There are measures to support creating small firms, vocational training and support for infrastructure investment.

A specific feature of the CAP is the so-called Leader-approach. It is strongly promoted by the EC and numerous rural organisations as offering a bottom-up approach to the development of local communities, as these specially created local action groups (generally with local NGOs and local authorities as members) prepare their own local development strategy. However, it proves not to be a panacea for the least developed regions as the complexity of programming procedures "might lead to a concentration of the benefits in stronger areas" [Crescenzi, Giua 2016]. In the programming period 2014-2020 this approach renamed as community-led local development, obligatory for rural development programmes co-financed by EAFRD, is extended as an option to ERDF, ESF and Common Fisheries Policy.

${ }^{2}$ Pillar 1 includes the measures financed by the European Agricultural Guarantee Fund (EAGF), while pillar 2 measures are financed by the European Agricultural Fund for Rural Development (EAFRD).

3 There are sometimes also significant differences in the names of measures between Polish RDPs and EU regulations specifying their aims and shape. 
In order to simplify analysing simultaneously cohesion policy and the CAP and their impact on rural development we should divide their instrument into four categories:

- Measures implemented in rural areas having direct impact on the rural development;

- Measures implemented in urban areas having direct impact on rural development;

- Measures not concentrated on any type of area influencing both rural and urban development;

- Measures implemented in urban areas having direct impact on urban development [FundEko 2011].

However, this approach to dividing support measures should be expended to the distinction of measures directly influencing agriculture, agri-food industry and other sectors of rural economy. This distinction should be made in order to show how diverse the development of rural areas is as the development of diverse economy makes the rural areas more resistant to crises and offers better job prospects and more attractive business climate and stay prospects. Yet, this is not the above division of measures that play the key role in determining the effectiveness and efficiency of both policies, but the actual aim of a given policy instrument. Generally investment measures have a higher positive impact on socio-economic development than transfers [Wieliczko (ed.) 2014]. As the factors determining effectiveness of support are named:

- Amount of support (high enough to trigger desired changes);

- Complexity and complementarity of undertaken projects;

- Implementation capacity [FundEco 2011].

\section{Rural development in Poland}

Rural development in Poland was accelerated by the inflow of the EU funds. The support started to be directed to the Polish rural areas before the Polish EU accession within such programmes as Phare or SAPARD. Yet, the EU accession was accompanied by a significant boost in the amount of funds and diversity of support measures.

It seems that the key impact of the EU funds on rural areas is the narrowing of gaps in infrastructure development among Polish rural communities. This especially applies to water management and waste management systems.

It has to be also underlined that a significant share of the funds flowing into the Polish regions are the funds from CAP. While most of the CAP funds are direct payments they are limited to agriculture and their use is not fully known. However, they are mostly spent on current or investment needs of farms receiving them. The share of CAP funds in the total amount of EU support coming to Polish voivodeships is correlated neither with the share of agriculture in their economies nor with the level of development of other sectors of the economy. However, generally the regions 
with the most developed agriculture have the highest share of the CAP funds in the total amount of EU support (tab. 1).

Table 1. Share of CAP funds (both RDPs and DPs) in the total amount of EU fund received by Polish regions in the period 2004-2011

\begin{tabular}{|l|c|c|c|}
\hline \multicolumn{1}{|c|}{ Region } & RDP & Direct payments & CAP \\
\hline Dolnośląskie & 10.41 & 29.01 & 39.42 \\
\hline Kujawsko-Pomorskie & 17.19 & 37.39 & 54.58 \\
\hline Lubelskie & 18.37 & 36.97 & 55.34 \\
\hline Lubuskie & 12.93 & 26.16 & 39.09 \\
\hline Łódzkie & 15.99 & 28.93 & 44.92 \\
\hline Małopolskie & 10.96 & 18.19 & 29.15 \\
\hline Mazowieckie & 15.04 & 26.51 & 41.55 \\
\hline Opolskie & 11.32 & 37.85 & 49.17 \\
\hline Podkarpackie & 11.06 & 18.1 & 29.16 \\
\hline Podlaskie & 21.88 & 39.36 & 61.24 \\
\hline Pomorskie & 11.39 & 26.22 & 37.61 \\
\hline Śląskie & 4.85 & 8.71 & 13.56 \\
\hline Świętokrzyskie & 16.45 & 24.15 & 40.60 \\
\hline Warmińsko-Mazurskie & 14.10 & 32.54 & 46.64 \\
\hline Wielkopolskie & 17.67 & 36.41 & 54.08 \\
\hline Zachodniopomorskie & 12.58 & 30.88 & 43.46 \\
\hline Average & 13.89 & 28.59 & 42.47 \\
\hline
\end{tabular}

Source: own elaboration based on [Masiąg et al. 2013].

Despite the constant inflow of EU funds the socio-economic development of the Polish rural areas is at most medium for most of the rural and urban-rural gminas (tab. 2). Moreover, there are visible differences between the regions in the share of medium and low developed rural and rural-urban gminas. The largest share of rural areas with very low and low level of economic development is observed in Podkarpackie and Lubelskie - over $70 \%$ of all rural and urban-rural gminas (the average for the whole country is $42 \%$ ). High and very high level of economic development is observed in $24.8 \%$ of the Polish rural and urban-rural gminas. The largest share of such gminas can be found in Zachodniopomorskie $-51.5 \%$, while over 2/5 of such gminas can be found in Dolmośląskie, Śląskie and Lubuskie.

The correlation between the percentage of rural gminas at different level of economic and social development reaches 0.58 . Thus, there are some similarities in the structure of gminas between economic and social development. However, according to Kołodziejczyk et al. [2015] there are more gminas with very low level of social development than the economic one. Yet, there are fewer gminas with low indicator of social development. When we add very low and low there are almost $38 \%$ of such gminas in Poland, while the ones assessed as high and very high in 
social development amount to $33 \%$. The lowest level of social development is observed in Podlaskie. Over 2/3 of gminas in this region are classified as representing very low level of social development. Adding the ones with low level of development this figure rises to over $85 \%$. Other regions with high share of very low and low developed rural areas are: Lubelskie, Warmińsko-Mazurskie and Świętokrzyskie. The largest share of gminas depicted as "very high" is noted in Śląskie - over 53\% and together with "high" ones it amounts to almost $80 \%$. It is worth mentioning that in Mazowieckie the share of such gminas amounts to $57 \%$. Thus, in this region we have highly developed country capital and surrounding it highly developed rural gminas and very low developed rural gminas in the peripheries of this voivodeship.

Table 2. Economic and social cohesion of rural areas in Poland in 2014 - share of rural and urban-rural gminas

\begin{tabular}{|c|c|c|c|c|c|c|}
\hline \multirow{2}{*}{\multicolumn{2}{|c|}{ Level of cohesion }} & \multicolumn{5}{|c|}{ Social development } \\
\hline & & \multirow{2}{*}{$\frac{\text { Very low }}{3.2}$} & \multirow{2}{*}{$\begin{array}{r}\text { Low } \\
2.1\end{array}$} & \multirow{2}{*}{$\frac{\text { Medium }}{0.8}$} & \multirow{2}{*}{$\begin{array}{c}\text { High } \\
0.2\end{array}$} & \multirow{2}{*}{$\begin{array}{c}\text { Very high } \\
0.0\end{array}$} \\
\hline \multirow{5}{*}{ 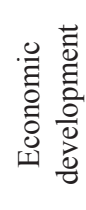 } & Very low & & & & & \\
\hline & Low & 8.2 & 12.1 & 10.8 & 4.2 & 0.7 \\
\hline & Medium & 2.6 & 7.0 & 12.4 & 7.3 & 3.5 \\
\hline & High & 0.5 & 1.5 & 3.2 & 4.5 & 4.6 \\
\hline & Very high & 0.1 & 0.6 & 1.8 & 2.3 & 5.7 \\
\hline
\end{tabular}

Source: own elaboration based on [Kołodziejczyk 2015].

In Poland in the programming period 2014-2020 the cohesion policy financial resources available within regional programmes targeted at rural areas are concentrated on following issues:

- Entrepreneurship development and better use of human capital, including vocational reorientation of farmers;

- Social and infrastructural revitalization;

- Water and sewage infrastructure [Ministerstwo Rozwoju 2015].

It is also estimated that within EU co-financed programmes implemented at national level there are resources to be spent in rural areas on:

- Broadband networks;

- Energy and anti-flood infrastructure;

- Youth and education;

- Entrepreneurship and transportation [Zygadło 2014].

As the observed differences in the level of socio-economic development among regions and gminas not only persist, but even increase there is a need to assess the necessity and feasibility of introducing a special mechanism of supporting the least developed local communities. This can be achieved not only by specially targeted policy instruments, but also by granting them more points in the project selection process and thus increasing their chances of receiving funds. The question of the way 
the funds should be divided among rural areas is the more piling as so far it was correlated with endogenous development potential [FundEko 2011]. Thus, the development gaps can further increase. Therefore there may be a need for special support for the most peripheral areas to ensure their vitality.

\section{Conclusions}

The developmental needs of rural areas are manifold and diverse. The key to effective developmental support lies in creating conditions for integrated development that makes the best use of the endogenous capacity of a given functional area [Kołodziejczyk 2015]. The difference between the development of rural and urban areas in Poland as well as in comparison with rural areas in other EU member states is still substantial, but it is acknowledged in developmental strategies and there are measures applied to tackle it. However, at the same time there are large and growing developmental gaps among Polish rural communities. Despite the implementation of special developmental programmes for eastern regions, these differences in socioeconomic development persist. Moreover, there are huge differences within richer regions that are not answered by any special measures. Naturally, it is difficult to fully assess the impact of particular policy instruments on the development as there are numerous other factors influencing it.

A good solution to this problem is the diversification of eligibility criteria or level of funding that offers rural preferential treatment to communities and entrepreneurs. This should apply especially to measures which beneficiaries are local authorities as the budgets at their disposal are significantly burdened with costs of providing basic public services to the local community and with a low level of economic development. As they do not have much other resources to improve attractiveness of their area and thus find themselves in a visions circle of underdevelopment with depopulation and aging adding to their problems.

It would be the best for rural development if cohesion policy and CAP worked in tandem and offered comprehensive and mutually strengthening measures. Yet, they still require more coordination to cover all the aspects of rural development that require support [Crescenzi et al. 2011]. However, we can see that there is more and more holistic planning at the country level where specific decisions have to be made on how to divide the funds among needs, regions and available policy instruments. This is most visible when we compare consecutive programming periods.

Notwithstanding the positive signs of cooperation and complementarity between the CAP and cohesion policy, it is still the CAP that is more associated with rural development and also more suited to it in terms of a clear focus and easier accessibility for rural beneficiaries. It seems that a simple way to boost the outreach of cohesion policy instruments targeted at rural areas is to employ the public relations channels that are used for rural development measures being implemented within the CAP. 
Given the key goal of cohesion policy, that is convergence of socio-economic development among the EU regions, it can also be stated that this policy is not the best suited option for rural areas as the disparities among rural areas enlarge in Poland. However, the results of the CAP are similar despite the fact that most of the financial resources are spent on direct payments and thus are received by all farmers with UAA and a lot of resources are devoted to less favourite areas which in Poland are still delimitated based not only on environmental and geographical characteristics, but also on the social ones - observed depopulation trend. Thus, less than a fifth depends on the capacity of potential beneficiary to co-finance the investment and therefore it is not closed to poorer regions.

As the funds available within the rural development programmes cannot satisfy all the needs of rural communities, rural beneficiaries have to reach for support from other sources. Moreover, rural areas should create links with local and regional growth centres that is with urban areas and this can be done more easily when cohesion policy funds are used as the scope of CAP rural development measures is limited.

\section{References}

Crescenzi R., De Filippis F., Pierangeli F., 2011, In tandem for cohesion? Synergies and conflicts between regional and agricultural policies of the European Union, LSE "Europe in Question" Discussion Paper Series No. 40/2011.

Crescenzi R., Giua M., 2014, The EU Cohesion policy in context: regional growth and the influence of agricultural and rural development policies, LEQS Paper No. 85/2014.

Crescenzi R., Giua M., 2016, EU cohesion policy in context: does a bottom-up approach work in all regions? Working Paper No 206/2016, Dipartimento di Economia Università degli studi Roma Tre.

Dorożyński T., 2012, Efektywność polityki spójności UE i jej wpływ na rozwój regionów, Międzynarodowe stosunki gospodarcze - integracja regionalna w Europie i na świecie, Studia Ekonomiczne Uniwersytetu Ekonomicznego w Katowicach No. 123, pp. 69-78.

FundEko, 2011, Wplyw wspólnej polityki rolnej i polityki spójności na rozwój obszarów wiejskich. Raport końcowy, FundEko, Warszawa.

Kołodziejczyk D. (ed.), 2015, Wieloaspektowe ujęcie problemu spójności obszarów wiejskich na poziomie lokalnym i regionalnym $w$ dotychczas realizowanych i planowanych strategiach rozwoju, Instytut Ekonomiki Rolnictwa i Gospodarki Żywnościowej - Państwowy Instytut Badawczy, Warszawa.

Ministerstwo Rozwoju, 2015, Programowanie perspektywy finansowej 2014-2020. Umowa Partnerstwa, Ministerstwo Rozwoju, Warszawa.

Misiąg J., Misiąg W., Tomalak M., 2013, Ocena efektywności wykorzystania pomocy finansowej Unii Europejskiej jako instrumentu polityki spójności społeczno-gospodarczej oraz poprawy warunków życia, Wyższa Szkoła Informatyki i Zarządzania z siedzibą w Rzeszowie, Rzeszów.

Wieliczko B. (ed.), 2014, "Agricultural budget" and the competitiveness of the Polish agriculture, Multi-annual Programme 2011-2014 no. 111.1, Institute of Agricultural and Food Economics National Research Institute, Warsaw.

Zygadło P., 2014, Polityka spójności w perspektywie finansowej UE na lata 2014-2020, a obszary wiejskie, Presentation on 16th May 2014 in Poznań. http://www.zgwrp.pl/attachments/article/575/ polityka\%20spojnosci\%20a\%20obszary\%20wiejskie_2014-20.pdf, 27.03.2017. 